This is the accepted manuscript of an article published by Taylor \& Francis in Globalisation, Societies and Education on Feb. 8, 2021. Please cite the version of record available online at: https://doi.org/10.1080/14767724.2021.1882957

Stephanie Leite

Ph.D. student, Department of Integrated Studies in Education, McGill University, Montreal, Canada

stephanie.leite@mail.mcgill.ca

\title{
Using the SDGs for global citizenship education: definitions, challenges, and opportunities
}

\begin{abstract}
The 17 United Nations Sustainable Development Goals (SDGs) employ a global indicator framework to detail each Goal and monitor its implementation. This article focuses on three targets from the indicator framework, which call for mainstreaming education for global citizenship, sustainable development, and climate change into national curricula. By investigating the practicalities of meeting these targets from an educator's perspective, this article proceeds with: arguing for a need to shift the central purpose of education; examining what is meant by education "for" the three key areas included in the global indicator framework; exploring curricular opportunities offered by the SDGs; and presenting inquiry-based learning as a pedagogical approach for critically interrogating the SDGs with learners. If the SDGs are used to drive a pragmatic definition of global citizenship, then trends in education such as inquiryand problem-based learning come to life with a clear and urgent purpose.
\end{abstract}

Keywords: Global citizenship education; Education for sustainable development; Climate change education; Inquiry-based learning; Sustainable Development Goals.

\section{Introduction}

In 2015, the United Nations (UN) adopted 17 Sustainable Development Goals (SDGs), together with a series of targets to clarify the intended outcomes of each Goal. In 2017, the UN General Assembly also adopted a global indicator framework, presented as a dynamic review mechanism used to guide and monitor the implementation of each Goal (UNStats, 
2021). Included in the global indicator framework is a call for increased education in three key areas: global citizenship, sustainable development, and climate change (I will frequently refer to these terms as "three key areas" of education). The achievement of the SDGs will thus in part be measured by the extent to which countries incorporate education on these three key areas into national curricula by 2030 (see Table 1). In order to help accomplish the SDGs within the given timeframe, educators need working definitions, so we have a shared understanding of what we are tasked to do. However, as of 2019 there was "no common agreement on the definitions of global citizenship education and education for sustainable development" (TCG, 2019, p. 4), while recent research has highlighted the significant differences in both engaging with and framing climate change within educational curricula (e.g., Bieler et al., 2018; Holthuis et al., 2014). For the purposes of this article, I will draw from definitions proposed in 2019 at the Sixth Meeting of the Technical Cooperation Group (TCG) (see Table 2).

Table 1. SDG Goals, Targets and Indicators Related to Education

\begin{tabular}{|c|c|c|}
\hline Goal & Target & Indicator \\
\hline $\begin{array}{l}\text { 4: Ensure inclusive } \\
\text { and equitable } \\
\text { quality education } \\
\text { and promote } \\
\text { lifelong learning } \\
\text { opportunities for all }\end{array}$ & $\begin{array}{l}\text { 4.7: By 2030, ensure that all learners } \\
\text { acquire the knowledge and skills needed } \\
\text { to promote sustainable development, } \\
\text { including, among others, through } \\
\text { education for sustainable development } \\
\text { and sustainable lifestyles, human rights, } \\
\text { gender equality, promotion of a culture } \\
\text { of peace and non- violence, global } \\
\text { citizenship and appreciation of cultural } \\
\text { diversity and of culture's contribution to } \\
\text { sustainable development }\end{array}$ & $\begin{array}{l}\text { 4.7.1: The extent to which (i) } \\
\text { global citizenship education } \\
\text { and (ii) education for } \\
\text { sustainable development, } \\
\text { including gender equality } \\
\text { and human rights, are } \\
\text { mainstreamed at all levels in } \\
\text { (a) national education } \\
\text { policies; (b) curricula; (c) } \\
\text { teacher education; and (d) } \\
\text { student assessment }\end{array}$ \\
\hline $\begin{array}{l}\text { 12: Ensure } \\
\text { sustainable } \\
\text { consumption and } \\
\text { production patterns }\end{array}$ & $\begin{array}{l}\text { 12.8: By } 2030 \text {, ensure that people } \\
\text { everywhere have the relevant } \\
\text { information and awareness for } \\
\text { sustainable development and lifestyles } \\
\text { in harmony with nature }\end{array}$ & $\begin{array}{l}\text { 12.8.1: The extent to which } \\
\text { (i) global citizenship } \\
\text { education and (ii) education } \\
\text { for sustainable development } \\
\text { (including climate change }\end{array}$ \\
\hline
\end{tabular}




\begin{tabular}{|l|l|l|}
\hline & & $\begin{array}{l}\text { education) are mainstreamed } \\
\text { in (a) national education } \\
\text { policies; (b) curricula; (c) } \\
\text { teacher education and (d) } \\
\text { student assessment }\end{array}$ \\
\hline $\begin{array}{l}\text { 13: Take urgent } \\
\text { action to combat } \\
\text { climate change and } \\
\text { its impacts }\end{array}$ & $\begin{array}{l}\text { 13.3: Improve education, awareness- } \\
\text { raising and human and institutional } \\
\text { capacity on climate change mitigation, } \\
\text { adaptation, impact reduction and early } \\
\text { warning }\end{array}$ & $\begin{array}{l}\text { 13.3.1: Number of countries } \\
\text { that have integrated } \\
\text { mitigation, adaptation, } \\
\text { impact reduction and early } \\
\text { warning into primary, } \\
\text { secondary and tertiary } \\
\text { curricula }\end{array}$ \\
\hline
\end{tabular}

Table 2. Definitions for GCED, ESD and CCE based on the TCG6 Report (2019)

\begin{tabular}{|l|l|}
\hline \multicolumn{1}{|c|}{ Term } & \multicolumn{1}{c|}{ Definition } \\
\hline $\begin{array}{l}\text { Global Citizenship } \\
\text { Education (GCED) }\end{array}$ & $\begin{array}{l}\text { Education which empowers learners of all ages to assume active roles, } \\
\text { both locally and globally, in building more peaceful, tolerant, inclusive } \\
\text { and secure societies. It can be summarised as 'learning to live } \\
\text { together'. It is based on the three domains of learning - cognitive, } \\
\text { socio-emotional and behavioural. } \\
\text { Cognitive: knowledge and thinking skills necessary to better } \\
\text { understand the world and its complexities. } \\
\text { Socio-emotional: values, attitudes and social skills that enable } \\
\text { learners to develop emotionally, psychosocially, and } \\
\text { physically and to enable them to live } \\
\text { together with others respectfully and peacefully. } \\
\text { Behavioural: conduct, performance, practical application and } \\
\text { engagement. It includes cultural diversity and intolerance, } \\
\text { gender equality and human rights and peace and non-violence. }\end{array}$ \\
\hline $\begin{array}{l}\text { Education for } \\
\text { Sustainable } \\
\text { Development (ESD) }\end{array}$ & $\begin{array}{l}\text { Education that empowers learners to take informed decisions and } \\
\text { responsible actions for environmental integrity, economic viability and } \\
\text { a just society for present and future generations. It can be summarised } \\
\text { as 'learning to live sustainably'. It covers sustainable lifestyles and } \\
\text { ways of life, climate change, biodiversity, environmental } \\
\text { sustainability, the greening of the economy and sustainable } \\
\text { consumption, caring for the planet and disaster risk reduction. }\end{array}$ \\
\hline $\begin{array}{l}\text { Climate Change } \\
\text { Education (CCE) }\end{array}$ & $\begin{array}{l}\text { Education to help people, in particular youth, understand, address, } \\
\text { mitigate, and adapt to the impacts of climate change. It encourages } \\
\text { changes in attitudes and behaviours needed to put the world on a more } \\
\text { sustainable development path and build a new generation of climate } \\
\text { change-aware citizens. It covers various responses to climate change } \\
\text { including mitigation, adaptation, impact reduction and early warning. }\end{array}$ \\
\hline
\end{tabular}


The three key areas are spread across three SDGs: Quality Education (Goal 4), Responsible Consumption and Production (Goal 12), and Climate Action (Goal 13). This separation has some utility in terms of developing learning objectives and assessments. However, the use of signifiers, such as "education for... XYZ," while indicating specific and urgent purposes, also relegates those purposes to the fringes of education itself (Jickling \& Sterling, 2017a; MGIEP, 2017). Jickling raised this point in 1992: "education is concerned with enabling people to think for themselves" and "education for anything else is inconsistent with that criterion" (Jickling, 1992, p. 8, emphasis added). Jickling's concern is still relevant today, as students and educators alike question the purpose of education and how it might address the turbulent social and environmental realities they confront daily.

Unless considered as a central purpose of education when incorporated into national curricula, the three key areas will remain supplemental to (and seemingly less important than) core academic subjects. Studying global citizenship as a unit of a Social Studies course or exploring climate change solely in a Science class inevitably confine these issues to niches, failing to present them as interrelated and interdependent (MGIEP, 2017). Instead of only associating those issues with subject experts, the SDGs as a whole may be used to support an integrated curriculum that combines environmental, social, and economic topics, encouraging a truly interdisciplinary perspective-notwithstanding their limitations (Sterling, 2016).

The organization of the 17 SDGs - which have assigned numbers but not explicit rankings in terms of importance-presents an opportunity to see issues as mutually dependent upon one another for their achievement. ${ }^{1}$ To offer an example, one cannot

\footnotetext{
${ }^{1}$ Evans and Musvipwa (2017, p. 43) have presented valid criticism regarding implicit hierarchies in
} the SDGs, which will be discussed later in this article. 
effectively address poverty (Goal 1) without also addressing access to clean energy (Goal 6) and gender equality (Goal 5). Assigning the SDGs different numbers separates the Goals into distinct issues that can be examined individually and in-depth; but when seen as a whole set, the Goals invite a holistic, integrated perspective. This structure allows us to zoom in and out, making the SDGs a dynamic pedagogical tool that can be used to define the three key areas. This dynamic ability begs the question: What if the purpose of education were to prepare students to address the issues identified in the SDGs? Instead of organizing school curriculum by subject, what if, adopting an inquiry-based learning (IBL) model, courses were oriented by themes, using the SDGs as a reference for defining localized learning objectives and outcomes?

Drawing from my experience working in secondary classrooms and teacher training programs in the United States, this article argues that the SDGs themselves may be employed to redefine education for global citizenship, sustainable development, and climate change, thus offering a purpose-driven framework for $21^{\text {st }}$-century learning. Using the 17 Goals as such opens a pathway for shifting education systems away from their focus on workforce preparation or uncritical economic growth — and towards the health and sustainability of our people and planet. This shift requires a re-examination of the fundamental values dominating formal schooling via a transformative learning theory; as Sterling argues: "education needs a significant degree of transformation itself [if] it is to be transformative in effect, rather than conformative" (Sterling, 2016, p. 211). Organizing curricula around the global issues identified in the SDGs is a starting point for transitioning our schools to help solve the greatest problems facing humanity. 


\section{The Need for Transformation}

Since the SDGs were adopted, a series of global crises have reached a tipping point and stirred a new generation of activists demanding accountability. The outrage demonstrated by youth is justified: global warming continues to threaten the Earth's climate stability as atmospheric carbon dioxide levels continue to rise. The planet's five warmest years on record have all happened since 2015 (NOAA, 2020), and scientists predict that existing levels of greenhouse gas emissions will already be felt for centuries to come (Mengel et al., 2018). Between 2017-2019, the planet's ability to absorb this carbon dioxide was further reduced by unprecedented fires in US, Australia, and Brazil; in this period, just the Amazon forest decreased in size by 4,500 square kilometers, an area almost twice the size of Luxembourg, due to deforestation and burning (Cannon, 2019). The resulting loss of biodiversity and animal habitat has also been linked to an increased vulnerability to pandemics such as SARS \& MERS (Plowright et al., 2008; Rizzo et al., 2017). In response to increased postcolonial migration to Europe, a 2016 wave of populism began to spread around the globe, with a series of nationalist parties gaining popularity and winning elections, threatening democratic institutions, and stoking xenophobia (WPR, 2019).

Youth have been active players in bringing issues such as the climate emergency and racial injustice to the attention of policy makers. The Global Climate Strike of 2019 saw at least 6 million people (Taylor et al., 2019) take to the streets when students and workers walked out in a coordinated demonstration that reached 125 countries (Milman, 2019). Eight months later, tens of thousands of protesters rallied against racial inequality after the police killing of George Floyd, an unarmed Black man in Minneapolis (Cave et al., 2020; Haddad, 2020a). Individuals in nearly 50 countries organized protests in solidarity with the U.S. 
(Haddad, 2020b), giving global prominence to the Black Lives Matter movement. Young people are at the forefront of a global reckoning, realizing they must inherit and confront centuries of social and environmental injustices.

So, what does it mean to be a global citizen today, and how do educators help students make sense of the historical context that has brought us to this moment? The issues calling protesters to the streets are not new, yet the convergence of so many makes it impossible to dispute their pronounced interconnections - and solutions must respond in an appropriately integrated manner (Rockström, 2015; Raworth, 2017). Anthropogenic climate change is directly linked to centuries of burning fossil fuels, leading to social and environmental consequences and revealing "the complexities of unequal distribution of impacts" (Cabello, 2009, p. 192). Priorities of a "colonial worldview with [a] capitalist mind-set" take nature for granted as a resource for humans to control and exploit for the sole purpose of economic growth (Meighan, 2020, p. 3). While technology may offer some solutions to issues such as the climate crisis, it alone does not address the historical and structural foundations of capitalism and our current challenges (Cabello, 2009; TWI2050, 2020). As we imagine and design transformative solutions to our current predicament, they must aim for systematic change - and not be limited to topical solutions such as carbon offsets and diversity quotas. The SDGs offer one possible framework for analyzing the intersectionality among urgent global issues and for providing a common language for educators to critically engage with the Goals. In addition, they give a clear purpose to global citizenship education —or education in general. 


\section{What Is Meant by Education for Global Citizenship, Sustainable Development, and Climate Change}

The SDG global indicator framework includes the 17 overarching Goals plus 169 targets and 247 indicators (UN, 2020). Three of the targets refer to education for sustainable development (ESD), global citizenship education (GCED) and/or climate change education (CCE) (see Table 1). The SDG indicators call for the integration of the three key areas into national curricula, but the indicators are expansive, and in and of themselves offer no baseline to measure progress for agencies and schools that are tasked with mainstreaming GCED, ESD, and CCE into their curricula (MGIEP, 2017, p. xvi). In 2019, the Technical Cooperation Group (TCG) on the Indicators for SDG 4 proposed definitions for monitoring the three key education-related indicators (see Table 2).

The TCG definitions add to a long history of inconsistencies and controversies in the attempt to define both global citizenship and sustainable development. As a relatively newer area of focus, disagreement on definitions of CCE are less widely documented; however, its political baggage also makes it a complicated issue that many schools avoid for fear of being labeled as "activist" (Sauvé, in Jobert, 2016). Beyond this overall unease with broaching the question of climate change in some constituencies, debates on CCE tend to focus more on how climate change is framed and situated within the curriculum. The analysis here focuses predominantly on GCED and ESD due to the long evolution of their conceptions and practical implementations.

The definitions in Table 2 themselves are fraught with contradictions that summarize the controversy surrounding ESD: how can ESD at the same time cover "environmental sustainability," "caring for the planet," "greening the economy," and "economic viability"? 
For environmental educators, using words such as environment, economy, and development together is immediately problematic. The contradictions found in the TCG's definitions are at the heart of the debate over ESD and its pressures to supplant environmental education (EE). In his 1996 survey of definitions related to environmental sustainability and sustainable development, Dobson identified over 300 definitions (p. 402). Environmental education acts as a more established umbrella for other trends, with sustainable development being just one of 15 "currents" in environmental education identified by Sauvé (2005) and recognized as one theory of environmental sustainability by Dobson (1996). While EE and ESD are often associated together and sometimes used interchangeably, it is important to understand the evolution of the terminology and the implications of adding the word "development" to the wider discourse on environmental education. With so many definitions and orientations, educators must critically engage with what is meant by differing conceptions of "the environment," "sustainable development," and even "education" itself (Sauvé, 1996, p. 9).

ESD is a more recent addition to the educational movements referred to as "education in relation to people and planet" (Wals et al., 2017). Stemming from nature conservation education and environmental education, ESD has also run parallel to a hybrid model of environmental and sustainability education that aims for a more relational way of understanding and being in the world (ibid.). While drawing in part on each of these movements, ESD has gained dominance in the global development lexicon since the term sustainable development was launched by the United Nations World Commission on Environment and Development and its release of the Brundtland Report, Our Common Future, in 1987 (Jickling \& Sterling, 2017b). Sustainable development took center stage again at the Rio Earth Summit in 1992, when environmentalists had been hopeful that a true transformation towards environmental sustainability would be embraced by capitalist 
countries (Evans \& Musvipwa, 2017). Nevertheless, the stated end-goal of development leaves some environmental educators uneasy and cautious of promoting a neoliberalist agenda in a direction that is predetermined, with researchers expressing concerns regarding the "emergence of education for sustainable development in educational policies and the pressure on the environmental educators around the world to re-frame their work as contributions towards sustainable development" (Jickling \& Wals, 2008, p. 4). Sauvé cautions that sustainable development, while relevant for business, should be resisted as an educational objective (in Jobert, 2016).

Classroom approaches to ESD vary depending on an individual's or institution's orientation and intended purpose (whether those intentions are conscious or not). For educators seeking to situate themselves in the ESD debate, the heuristic proposed in 2008 by Jickling and Wals is useful in positioning one's approach to and understanding of the relationship between education and sustainable development. Set up as a four-quadrant grid, the heuristic captures on one axis two conceptions of education (transmissive and transformative) and on the other axis two corresponding views of an "educated person" and their role in society (authoritative and participatory). Jickling and Wals (2008) questioned whether the "globalizing forces" (p. 18) associated with ESD allow for transformative approaches to education that enable students to develop environmental thought without a predetermined outcome in mind.

The ESD conversation is enriched from a sociopolitical and socioeconomic perspective by Rose and Cachelin (2018), who differentiate between noncritical and critical sustainability practices; noncritical forms "maintain abusive power dynamics that remain in place as far as these can be "sustained"” (Rose \& Cachelin, 2018, p. 519). In contrast, 
Critical sustainability recognizes the material, ecological necessities that sustain all life on the planet, while also acknowledging and seeking out sociopolitical orientations that support dignity, equity, respect, and rights for all parties. Critical sustainability explicitly refutes the commodification of "nature," seeking instead a biopolitical organization of social life that envisions human and nonhuman flourishing as fitting well within the limits of ecological systems. And rather than thinking about the concept as a single, unifying model, it is more appropriate to think about critical sustainabilities in the plural, where local articulations are context-dependent, contingent on any number of political, environmental, and/or cultural factors (Rose \& Cachelin, 2018, p. 521; emphasis in the original).

Educators can draw from the distinction between critical and noncritical sustainabilities to position their own approach and orient their curricular decisions.

Like the debate over ESD, the discussion over GCED has been contentious, with no shortage of associated purposes and terms. Often taught in civics and social studies classes, the idea of GCED is also connected to initiatives such as human rights education, peace education, and democratic education, among others (Oxley \& Morris, 2013, p. 302). In Western education systems, the inclusion of civics education in national curricula often plays the role of promoting social cohesion and developing a shared identity and the obligations to a specific community or nation (Mburu, 2012, p. 176). This attempt to establish a national or collective identity has been controversial in many regions, especially those with high multiculturalism or a history of colonialism, or where rights have been restricted or withheld from specific populations (DeJaeghere, 2009; Deer, 2009). DeJaeghere (2009), for instance, reminds us that by definition "citizenship" is exclusionary (p. 223); and Camicia and Franklin (2011) contend that citizenship education "has been a tool for perpetuating national myths that construct and maintain imagined consensus in, on the surface, the name of national unity" (p. 311). 
With such challenges at the national level, efforts to establish a global identity are even more amorphous (Gaudelli \& Fernekes, 2004). One widespread concept of global citizenship, rooted in the ancient Greek idea of cosmopolitanism, grew after World War II, out of the search for a common humanity and our ethical responsibilities to fellow humans (Reimers et al., 2016). The creation of the United Nations and the ensuing Universal Declaration of Human Rights have made the concept of global citizenship a central but challenging endeavor in education (Gaudelli, 2004). In Western thought, global citizenship has inherently been tied to humans and to inclusion in a larger, shared "species identity" (Boulding 1988; Gaudelli \& Fernekes, 2004, p. 17). The Euro-American definition of citizenship, according to Anishinaabe legal scholar John Borrows, "is not consistent with holistic notions of citizenship that must include the land, and all beings upon it" (Borrows, 2002, p. 141); that is to say, the dominant understanding of global citizenship is still humancentered and, for the last four centuries, it has promoted relationship between nature and society through an overwhelmingly anthropocentric - as opposed to ecocentric-lens (Smith, 1998; Jelin, 2000).

As GCED continues to gain momentum, educators must, as with ESD, have a clear understanding of the intents of such programs and curriculum. In 2006, Andreotti proposed a distinction: soft GCED, motivated by charity and a sense of humanitarianism rooted in the idea of a shared common humanity; and critical GCED, motivated by ethical responsibility towards justice and by the recognition of alternative conceptualizations of development (Andreotti 2006, 2014). Building upon Andreotti's work, Camicia and Franklin (2011) distinguish between two discourses for understanding global community: neoliberal cosmopolitanism and critical democratic cosmopolitanism. The former stresses market rationality, while the latter emphasizes social justice and deliberative democracy (p. 314). 
Camicia and Franklin point out that these discourses are not binary, but "embedded in a dynamic network of power relations" (ibid.).

Expanding on her own soft/critical GCED conceptualization, Andreotti maps three configurations of "social engineering"- all rooted in European colonialism or the resistance to it (2014, p. 42). She adds a fourth "Other" narrative to this cartography, represented simply by a question mark, arguing that the majority of people who have participated in formal schooling have been blinded "to other forms of seeing, knowing and being in the world that do not fit what we can recognize through the frames of reference we have become used to" (p. 45); thus our ability to imagine other possibilities has been restricted. Adapting a heuristic developed by Andreotti et al. (2016), a typology by Pashby et al. (2020) maps GCED types across a triadic organization of discursive orientations: neoliberal, liberal, and critical — and the interplay among them (p. 145). Of the nine types included in the mapping, the greatest confluence occurrs on the neoliberal orientation, with only two GCED types mapping directly onto the critical orientation. This is consistent with Andreotti's identification of our limited ability to imagine outside the powerful "modern/colonial imaginary" (Pashby et al., 2020, p. 156). Awareness of these interwoven discourses and the ultimate objective of each should inform educators building and delivering curriculum for global citizenship.

\section{Curricular Opportunities in the Sustainable Development Goals}

The SDGs bring with them all the controversies and contradictions surrounding ESD, GCED, and CCE. When approached acritically, the SDGs "remain anchored in neo-liberal economic policies that entrench the capitalist interests of the North" instead of serving as a "panacea to global inequality and disintegration" (Evans \& Musvipwa, 2017, p. 37). Critics further argue that, with the United Nations leading the discourse on climate change and sustainable 
development, the economic priorities of the North will subject both climate change mitigation and poverty reduction "to the principles of profit-making, market forces, and market growth" (idem, p. 38). If taken as technocratic economic indicators external to our daily actions and education systems, the SDGs, like the Millennium Development Goals that preceded them, may "serve mostly to legitimate an extremely unequal world system in which literally billions of people are relegated to a marginalized existence-legitimating this world by promising we are addressing its severe problems" (Klees, 2017, p. 436).

What is an educator to do? Our interwoven economic, social, and environmental crises are "also a crisis of education," which "continues to be restructured in most parts of the world to better reproduce workers, consumers and citizens who meet the needs of neoliberal capitalism" (Huckle \& Wals, 2015, p. 493). There is a common assumption that schooling is about preparing students to feed the global economy; yet "there's something deeply disturbing about regarding children mostly as future employees and reducing education to an attempt to increase the profitability of corporations" (Strauss, 2013). How do educators shift the purpose of education beyond workforce preparation while also adequately recognizing the context and challenges students face upon graduation? As Sterling points out:

The future seems to be regarded by the mainstream as some sort of constant, assured, and stable, whilst the normal business of educating/training for jobs and any kind of economic growth proceeds untrammelled and unbothered by notions of: resource depletion and competition, poverty and growing inequity, marginalisation of minorities, spreading fundamentalism, extremism and terrorism, the implications of the march of bioscience and robotics, species loss and plummeting biodiversity, climate change, food security, wars and civil unrest, the risk of global pandemics, and so on (Sterling, 2017, p. 36). 
As an educator, disregarding the inevitability of these crises feels irresponsible. But education systems are complex and slow to change. How do teachers in primary, secondary, and post-secondary schools develop the tools, resources, and leadership to galvanize actual change in a world desperately in need of facing its biggest problems?

Despite the critiques, the SDGs are a globally recognized "blueprint" that proclaim to have "sustainability for all" as a primary aim (UN, 2015). Sterling (2019) acknowledges the SDGs as "a necessary and timely response to the world problematique" (p. 61) while also posing an important question: "What factors have led to planetary system conditions - here in the early $21^{\text {st }}$ century — such that a set of remedial UN SDGs are necessitated?” (p. 62). As educators, how do we both appreciate the SDGs as a common reference for global priorities and critique the systems that made them priorities in the first place? Instead of simply disregarding the SDGs as a tool of the global neoliberalist agenda, we can take advantage of the opportunity they present to reinvent curriculum around a shared set of urgent issues that our global community must address. The controversy surrounding the SDGs — and the related three key areas - is what makes the SDGs a valuable organizing framework for educators.

The 17 SDGs encompass a broad range of issues that can be examined and critiqued on many different levels. The ability and responsibility to examine these issues on personal, local, and global levels could be used to reorient the definition of GCED. And $21^{\text {st }}$-century education itself could be defined by prioritizing GCED, ESD, and CCE. As adults continue to wrestle with definitions, we need to invite students into the intellectual debate instead of waiting for a "nice neat 'vision' or plan" to guide action (Brennan, 2019, p. 2). It is our students who will determine the post-2030 global agenda - so why not bring them into the debate now? 
Concerns about the SDGs are justified and should be encouraged; if the SDGs are taken by educators as prescriptive, they may perpetuate neoliberal interests as critics such as Evans and Musvipwa warn us (2017). Likewise, to acritically include the SDGs in curricula — simply as a list of issues to learn about —will perpetuate a transmissive form of education whereby students become receptacles for a predetermined agenda (Jickling \& Wals, 2008); in this way, the SDGs become just one more subject to learn. On the other hand, using a constructivist philosophy in which learners actively contribute to and shape the learning, the SDGs can be an empowering resource to invite civic reflection, critical thinking, debate, and innovation.

\section{Inquiry-Based Learning as a Pedagogical Approach}

The inclusion of ESD, GCED, and CCE in the SDGs is a recommendation of what should be included in national curricula, but now how; the SDGs do not provide a recommended pedagogical approach. However, UNESCO, appointed as the "custodian agency" for Target 4.7 (UNESCO, 2019), acknowledges a pedagogical reorientation is necessary, in their 2016 Global Education Monitoring Report (GEM). Wals (2016) observes that while the GEM Report is easily critiqued as "an extension of hegemonic globalizing thinking" it also includes "a potential shift," representing an evolution in "mainstream UN-speak." This potential shift is evidenced by statements in the Report such as, "for education to truly be transformative, 'education as usual' will not suffice," and "learning needs to foster thinking that is more relational, integrative, empathic, anticipatory and systemic" (UNESCO, 2016, p. 163). To address the SDGs, both classroom resources and the instructional methods need to be rethought. This poses multiple challenges, considering how deeply entrenched the "education as usual" model has been embedded in teacher training, classroom resources, and educational 
institutions. How do we begin to make a shift?

Inquiry-Based Learning (IBL) and its related "cluster of teaching and learning strategies" (Blessinger \& Carfora, 2015, p. 5) offer an entry point for investigating the SDGs with students. Also associated with real-world, problem-, project-, and place-based learning, IBL is a student-centered approach based on problem scenarios that encourage students to critically interrogate themselves, their communities, and the nature of the problems they are investigating (Herman \& Pinard, 2015). The IBL approach to learning predates Socrates as a "method of developing self-knowledge through intensive questioning" (Jones, 2015, p. 277). Further developed by constructivist theorists such as Dewey, Vygotsky, Piaget, and Bruner, the inquiry method allows students "a means by which to construct their own knowledge rather than just having that knowledge merely spoon-fed to them by others" (Blessinger \& Carfora, 2015, p. 5).

A key component of IBL is the active role taken on by learners in shaping the questions, purpose, and path of discovery. The traditional relationship between teacher and student is thus disrupted, which can be a difficult transition as participants develop new attitudes about classroom roles, the purpose of teaching, and the nature of learning (ibid.). A skillfully designed and facilitated IBL environment is collaborative, multi-disciplinary, empowering, and purposefully unpredictable. For some educators, the classroom debates and outcomes arising from inquiry may be uncomfortable, removing them from the dominant "sage on the stage" role; however, practiced IBL facilitators use dialog to "contextualize problems and help to critically inform or nuance student arguments" (Herman \& Pinard, 2015, p. 52). IBL may disarm teachers who have been conditioned in the very structures that are the target of transformation and help cultivate a learning environment that acknowledges we do not yet have answers to the complex issues under investigation. Sund and Pashby 
(2020) observe the challenges educators face in teaching global issues, "given the complex ways teachers are or not prepared to engage in ethical global issues pedagogy," nor confront colonial systems of power (p. 166). To move beyond surface-level inquiry, Andreotti's HEADS UP tool helps educators deepen the level of questioning around "seven problematic historical patterns of thinking and relationships" that often frame educational engagements with global issues: hegemony, ethnocentrism, ahistoricism, depoliticization, salvationism, uncomplicated solutions, and paternalism (2012, p. 2). Utilizing such a resource facilitates difficult discussions and guides educators in "their own critically reflexive practice" (Pashby $\&$ Sund, 2020). With the SDGs as an object of examination, an IBL approach creates space for such difficult conversations and reflexivity to occur, inviting teachers and learners to see the connections - and contradictions - between each of the 17 SDGs. The tensions arising in such a classroom setting may serve as "prerequisites rather than barriers" from a learning perspective (Jickling \& Wals, 2008, p. 5).

While systematic educational transformation is daunting, changing the way we think about subjects offers a starting point for rethinking what all this might look like at the classroom level. Flipping the focus of classrooms from segregated subjects-which perpetuate siloed thinking — to interdisciplinary themes opens up possibilities for learning:

Indeed, subjects are at the heart of our modern dilemma [...] a subject-centered approach yields a deficit model of instructional design, wherein teachers, curriculum designers, textbook producers and test developers identify "gaps" in the learner's knowledge and develop plans to close them. Meanwhile, the "minor" subjects, such as art, music, physical education, which, ironically, are the pathway for many to deeper learningdon't count in contemporary achievement metrics... What if educators approached their discipline as a lens for understanding the world, not simply as a body of knowledge to be mastered? (Riordan \& Caillier, 2019, 130-1). 
The SDG targets provide abundant fodder for teachers to design and facilitate inquiry-driven investigations with the ultimate goal of critical engagement with the world. Examining the very first SDG target (1.1), some of these possibilities may be explored by considering links with traditional subject matter (see Table 3).

Table 3. Pedagogical Opportunities for SDG Target 1.1

\begin{tabular}{|l|l|l|}
\hline \multicolumn{1}{|c|}{ SDG Target } & \multicolumn{1}{|c|}{ Guiding Questions } & Traditional Subject Conversion \\
\hline $\begin{array}{l}\text { 1.1: By 2030, } \\
\text { eradicate extreme } \\
\text { poverty for all } \\
\text { people everywhere } \\
\text { currently measured } \\
\text { as people living on } \\
\text { less than \$1.25 a day }\end{array}$ & Who defines poverty? Why? & Philosophy \\
\cline { 2 - 3 } & $\begin{array}{l}\text { What are the roots of poverty? Why } \\
\text { does poverty exist? }\end{array}$ & History \\
\cline { 2 - 3 } & $\begin{array}{l}\text { How is \$1.25 calculated? What is a } \\
\text { poverty line and how is it calculated? }\end{array}$ & Mathematics \\
\cline { 2 - 3 } & What is it like to live on \$1.25 a day? & Sociology \\
\cline { 2 - 4 } & $\begin{array}{l}\text { Is \$1.25 a day just? What would be } \\
\text { "just" and why? }\end{array}$ & Ethics \\
\cline { 2 - 3 } & $\begin{array}{l}\text { How could the global poverty line be } \\
\text { raised? How can we imagine a world } \\
\text { where poverty doesn't exist? }\end{array}$ & Economics \\
\hline
\end{tabular}

Using the SDGs as a list of essential topics to explore in the classroom invites localization, customization, and cultural responsiveness (see Hammond, 2015). It allows students to make connections at personal, local, and global levels, seeing the intersectionality of issues both within and among the 17 Goals. A "student-framed" approach to IBL creates space for students to define their own questions (Marquis \& Tam, 2015), thereby increasing authenticity, self-determination, and curiosity. The practice of collaborative inquiry can also serve a first step towards transformative learning, which involves making deep shifts in the way we think, act, and exist in the world (Laininen, 2019; Sterling, 2010). In an unpredictable 
world, this ability to ask ongoing questions and adapt to new situations is a key attribute of a critically thinking and engaged global citizen.

\section{Conclusion}

The UN prioritizes education for three key areas in its 2030 agenda: global citizenship, sustainable development, and climate change. Instead of dismissing these signifiers as “dissatisfying and ultimately empty," I argue they can call us to "do some more fundamental rethinking of education and its purposes in a rapidly changing global context" (Jickling \& Sterling, 2017, pp. 5-6). There has been ongoing debate over the meaning, purpose, and framing of these terms; however, if practitioners look beyond what the SDGs say and invite learners to investigate why the 17 issues are prioritized as areas of global concern, then they become generative educational opportunities. Applying an inquiry-based approach that positions learners as co-designers driving investigations, the SDGs may be localized, interrogated, and used as a springboard for deeper examination of the issues themselves and of why they are in need of attention.

With global learning trends entrenched in efforts towards standardization, any revision to existing educational systems seems daunting. Yet, the quality of our collective future rests on our "capacity and ability to learn and change" (Sterling, 2014, p. 90). Given the abundant examples of recent youth-led civic demonstrations, students are not waiting for top-down reforms to happen, and educators must respond with change starting in their own classrooms. It is time for the purpose and structure of schools to be fundamentally transformed, initiating a process of unlearning (Sterling, 2017; Laininen, 2019) that is not simply about "reframing or reconstructing our current thinking but moving away from our existing mental structures towards a position which enables a fundamentally different way of 
seeing the world" (Laininen, 2019, p. 177). Instead of being seen as a "technical toolbox," the SDGs may contribute to a "living tradition of inquiry" (MGIEP, 2017, p. 2) and serve as a common, globally-recognized reference point for educators. As the conversation surrounding the SDGs goes on, our planet continues to warm and inequities to grow. If we use the SDGs to drive a pragmatic definition of global citizenship education, then pedagogical approaches such as inquiry- and problem-based learning come to life with a clear and urgent purpose.

\section{Acknowledgements}

I would like to thank Ying-Syuan (Elaine) Huang, Blane Leslie Harvey, Carlos Pittella, and the journal's reviewers for their helpful comments on earlier versions of this article. I would also like to recognize Global Citizenship Experience Lab School in Chicago for fostering the innovative environment that helped shape my ideas on GCED.

\section{References}

Andreotti, V. Stein, S., Pashby, K., \& Nicolson, M. (2016). Social cartographies as performative devices in research on higher education. Higher Education Research \& Development, 35(1), 84-99. https://doi.org/10.1080/07294360.2015.1125857

Andreotti, V. (2014). Critical and transnational literacies in international development and global citizenship education. Sisyphus Journal of Education, 2(3), 32-50.

Andreotti, V. (2012). Editor's preface: HEADS UP. Critical Literacy: Theories and Practices, 6(1), 1-3.

Andreotti, V. (2006). Soft vs. critical global citizenship education. Policy and Practice: A Development Education Review, 3, 40-51. https://www.developmenteducationreview.com/issue/issue-3/soft-versus-criticalglobal-citizenship-education

Bieler, A., Haluza-Delay, R., Dale, A., \& Mckenzie, M. (2018). A national overview of climate change education policy: Policy coherence between subnational climate and 
education policies in Canada (K-12). Journal of Education for Sustainable Development, 11(2), 63-85. https://doi.org/10.1177/0973408218754625

Blessinger, P. \& Carfora, J. M. (2015). Innovative approaches in teaching and learning: An introduction to inquiry-based learning for multidisciplinary programs. In P. Blessinger \& J. M. Carfora (Eds.), Inquiry-Based Learning for Multidisciplinary Programs: A Conceptual and Practical Resource for Educators (pp. 3-22). Emerald Group Publishing Limited. https://doi.org/10.1108/S2055-364120150000003001

Borrows, J. (2002). Recovering Canada: The Resurgence of Indigenous Law. University of Toronto Press.

Boulding, E. (1988). Building a global civic culture: Education for an interdependent world. Teachers College Press.

Brennan, M. (2019). Changing teacher and teacher education in the 'Anthropocene.' On Education. Journal for Research and Debate, 2(4), 1-6. https://doi.org/10.17899/on ed.2019.4.6

Cabello, J. (2009). The politics of the clean development mechanism: hiding capitalism under the green rug. In S. Böhm \& S. Dabhi (Eds.), Upsetting the offset: The political economy of carbon markets (pp. 192-202). MayFlyBooks. http://mayflybooks.org/?p=206

Camicia, S. P., \& Franklin, B. M. (2011). What type of global community and citizenship? Tangled discourses of neoliberalism and critical democracy in curriculum and its reform. Globalisation, Societies and Education, 9(3-4), 311-322. https://doi.org/10.1080/14767724.2011.605303

Cannon, J. (2019, Nov. 14). Deforestation preceded fires in 'massive' area of Amazon in 2019. Mongabay. https://news.mongabay.com/2019/11/deforestation-preceded-fires-inmassive-area-of-amazon-in-2019/

Cave, D., Albeck-Ripka, L., \& Magra, I. (2020, Jun. 9). Huge Crowds Around the Globe March in Solidarity Against Police Brutality. The New York Times. https://www.nytimes.com/2020/06/06/world/george-floyd-global-protests.html

Deer, F. (2009). Aboriginal students and the delivery of citizenship education. Canadian and International Education, 38(2), 23-35. https://doi.org/10.5206/cie-eci.v38i2.9134

DeJaeghere, J. G. (2009). Critical citizenship education for multicultural societies. Interamerican Journal of Education for Democracy, 2(2), 223-236. https://scholarworks.iu.edu/journals/index.php/ried/article/view/159/253

Dobson, A. (1996). Environmental sustainabilities: An analysis and a typology. Environmental Politics, 5(3), 401-428. https://doi.org/10.1080/09644019608414280

Evans, H-C., \& Musvipwa, R. K. (2017). The Sustainable Development Goals, the Paris Agreement and the Addis Agenda: Neo-liberalism, unequal development and the rise of 
a new imperialism. In T. Halvorsen, H. Ibsen, H-C. Evans \& S. Penderis (Eds.), Knowledge for justice: Critical perspectives from Southern African-Nordic research partnerships (pp. 37-56). African Minds. https://doi.org/10.5281/zenodo.1092690

Gaudelli, W., \& Fernekes, W. R. (2004). Teaching about global human rights for global citizenship. The Social Studies, 95(1), 16-26. https://doi.org/10.3200/TSSS.95.1.16-26

Haddad, M. (2020b, Jun. 7). Mapping anti-racism solidarity protests around the world. $A l$ Jazeera. https://www.aljazeera.com/indepth/interactive/2020/06/mapping-anti-racismsolidarity-protests-world-200603092149904.html

Haddad, M. (2020a, Jun. 2). Mapping US cities where George Floyd protests have erupted. Al Jazeera. https://www.aljazeera.com/indepth/interactive/2020/06/mapping-citiesgeorge-floyd-protests-erupted-200601081654119.html

Hammond, Z. (2015). Culturally responsive teaching \& the brain: Promoting authentic engagement and rigor among culturally and linguistically diverse students. Corwin.

Herman, W. E., \& Pinard, M. R. (2015). Critically examining inquiry-based learning: John Dewey in theory, history, and practice. In P. Blessinger \& J. M. Carfora (Eds.), InquiryBased Learning for Multidisciplinary Programs: A Conceptual and Practical Resource for Educators (pp. 43-62). Emerald Group Publishing Limited. https://doi.org/10.1108/S2055-364120150000003016

Holthuis, N., Lotan, R., Saltzman, J., \& Mastrandrea, M. (2014). Supporting and understanding students' epistemological discourse about climate change. Journal of Geoscience Education, 62(3), 374-387. https://doi.org/10.5408/13-036.1

Huckle, J., \& Wals, A. E. J. (2015). The UN Decade of Education for Sustainable Development: Business as usual in the end. Environmental Education Research, 21(3), 491-505. https://doi.org/10.1080/13504622.2015.1011084

Jelin, E. (2000). Towards a global environmental citizenship? Citizenship Studies, 4(1), 4763. https://doi.org/10.1080/136210200110021

Jickling, B., \& Sterling, S. R. (Eds.) (2017a). Post-sustainability and environmental education: remaking education for the future. Cham: Palgrave Macmillan. https://doi.org/10.1007/978-3-319-51322-5_1

Jickling, B., \& Sterling, S. R. (2017b). Post-sustainability and environmental education: Framing issues. In B. Jickling \& S. Sterling (Eds.), Post-Sustainability and Environmental Education (pp. 1-11). Cham: Palgrave Macmillan. https://doi.org/10.1007/978-3-319-51322-5

Jickling, B., \& Wals, A. E. J. (2008). Globalization and environmental education: looking beyond sustainable development. Journal of Curriculum Studies, 40(1), 1-21. https://doi.org/10.1080/00220270701684667 
Jickling, B. (1992). Viewpoint: Why I don't want my children to be educated for sustainable development. The Journal of Environmental Education, 23(4), 5-8. https://doi.org/10.1080/00958964.1992.9942801

Jobert, M. (2016, Sep. 13). Lucie Sauvé: Schools avoid climate change for fear of being 'controversial.' Euractiv. $\quad$ https://www.euractiv.com/section/climateenvironment/interview/lucie-sauve-schools-avoid-climate-change-for-fear-of-beingcontroversial/

Jones, D. E. (2015). The life arts project: Application of an inquiry-based learning model for adult learners. In P. Blessinger \& J. M. Carfora (Eds.), Inquiry-Based Learning for Multidisciplinary Programs: A Conceptual and Practical Resource for Educators (pp. 275-288). Emerald Group Publishing Limited. https://doi.org/10.1108/S2055$\underline{364120150000003031}$

Klees, S. J. (2017). Will we achieve education for all and the education sustainable development goal? Comparative Education Review, 61(2), 425-440. https://doi.org/10.1086/691193

Laininen, E. (2019). Transforming our worldview towards a sustainable future. In J. W. Cook (Ed.), Sustainability, human well-being, and the future of education (pp. 161-200). Palgrave Macmillan, Cham. https://doi.org/10.1007/978-3-319-78580-6_5

Marquis, B., \& Tam, V. (2015). Developing an interdisciplinary inquiry course on global justice: An inquiry-informed, cross-campus, collaborative approach. In P. Blessinger \& J. M. Carfora (Eds.), Inquiry-Based Learning for Multidisciplinary Programs: A Conceptual and Practical Resource for Educators (pp. 101-118). Emerald Group Publishing Limited. https://doi.org/10.1108/S2055-364120150000003021

Mburu, W. (2012). Indigenous conceptions of civic education: Reinventing the past. In A. Asabere-Ameyaw, G. J. Sefa Dei \& K. Raheem (Eds.), Contemporary issues in African sciences and science education (pp. 175-193). Sense Publishers. https://doi.org/10.1007/978-94-6091-702-8_11

Meighan, P. (2020). Decolonizing English: A proposal for implementing alternative ways of knowing and being in education. Diaspora, Indigenous, and Minority Education. Advance online publication. https://doi.org/10.1080/15595692.2020.1783228

Mengel, M., Nauels, A., Rogelj, J., \& Schleussner, C-F. (2018). Committed sea-level rise under the Paris Agreement and the legacy of delayed mitigation action. Nature Communications, 9(601), 1-10. https://doi.org/10.1038/s41467-018-02985-8

MGIEP - Mahatma Gandhi Institute of Education for Peace and Sustainable Development. (2017). Rethinking schooling for the 21" century. The state of education for peace, sustainable development and global citizenship in Asia. UNESCO. https://unesdoc.unesco.org/ark:/48223/pf0000260568 
Milman, O. (2019, Sep. 20). US to stage its largest ever climate strike: 'Somebody must sound the alarm'. The Guardian. https://www.theguardian.com/world/2019/sep/20/climatestrikes-us-students-greta-thunberg

NOAA - National Oceanic and Atmospheric Administration (2020, Jan. 15). 2019 was $2^{\text {nd }}$ hottest year on record for Earth say NOAA, NASA. NOAA News. https://www.noaa.gov/news/2019-was-2nd-hottest-year-on-record-for-earth-say-noaa$\underline{\text { nasa }}$

Oxley, L. \& Morris, P. (2013). Global citizenship: A typology for distinguishing its multiple conceptions. British Journal of Educational Studies, 61(3), 301-325. https://doi.org/10.1080/00071005.2013.798393

Pashby, K., da Costa, M., Stein, S. \& Andreotti, V. (2020). A meta-review of typologies of global citizenship education. Comparative Education, 56(2), 144-164. https://doi.org/10.1080/03050068.2020.1723352

Pashby, K. \& Sund, L. (2020). Critical GCE in the era of SDG 4.7: Discussing HEADSUP with secondary teachers in England, Finland, and Sweden. In D. Bourn (Ed.), The Bloomsbury Handbook of Global Education and Learning (pp. 314-326). Bloomsbury Academic.

Plowright, R. K., Field, H. E., Smith, C., Divljan, A., Palmer, C., Tabor, G., Daszak, P., \& Foley, J. E. (2008). Reproduction and nutritional stress are risk factors for Hendra virus infection in little red flying foxes (Pteropus Scapulatus). Proceedings of the Royal Society B. Biological Sciences, 275, 861-869. https://doi.org/10.1098/rspb.2007.1260

Raworth, K. (2017). Doughnut economics: Seven ways to think like a $21^{\text {s-century economist. }}$ Random House.

Reimers, F., Chopra, V., Chung, C. K., Higdon, J., \& O’Donnell, E. B. (2016). Empowering global citizens: A world course. CreateSpace Independent Publishing Platform.

Riordan, R., \& Caillier, S. (2019). Schools as equitable communities of inquiry. In J. W. Cook (Ed.), Sustainability, human well-being, and the future of education (pp. 121-160). Palgrave Macmillan, Cham. https://doi.org/10.1007/978-3-319-78580-6_4

Rizzo, F., Edenborough, K. M., Toffoli, R., Culasso, P., Zoppi, S., Dondo, A., Robetto, S., Rosati, S., Lander, A., Kurth, A., Orusa, R., Bertolotti, L., \& Mandola, M. L. (2017). Coronavirus and paramyxovirus in bats from Northwest Italy. BMC Veterinary Research, 13, Article 396. https://doi.org/10.1186/s12917-017-1307-x

Rockström, J. W. (2015). Bounding the planetary future: Why we need a great transition. A Great Transition Initiative Essay. Great Transition Initiative, Apr. 2015 issue. https://www.tellus.org/pub/Rockstrom-Bounding the_Planetary_Future.pdf 
Rose, J., \& Cachelin, A. (2018). Critical sustainability: Incorporating critical theories into contested sustainabilities. Journal of Environmental Studies and Sciences, 8, 518-525. https://doi.org/10.1007/s13412-018-0502-9

Sauvé, L. (2005). Currents in environmental education: Mapping a complex and evolving pedagogical field. Canadian Journal of Environmental Education, 10, 11-37. https://files.eric.ed.gov/fulltext/EJ881772.pdf

Sauvé, L. (1996). Environmental education and sustainable development: A further appraisal. Canadian Journal of Environmental Education, 1, 7-34. https://files.eric.ed.gov/fulltext/EJ540073.pdf

Smith, M. J. (1998). Ecologism: Towards ecological citizenship. University of Minnesota Press.

Sterling, S. (2019). Planetary primacy and the necessity of positive dis-illusion. Sustainability, 12(2), 60-66. https://doi.org/10.1089/sus.2019.29157

Sterling, S. (2017). Assuming the future: Repurposing education in a volatile age. In B. Jickling \& S. Sterling (Eds.), Post-Sustainability and Environmental Education (pp. 3145). Palgrave Macmillan, Cham. https://doi.org/10.1007/978-3-319-51322-5_3

Sterling, S. (2016). A commentary on education and sustainable development goals. Journal of Education for Sustainable Development, 10(2), 208-213. https://doi.org/10.1177/0973408216661886

Sterling, S. (2014). Separate tracks or real synergy? Achieving a closer relationship between education and SD, post-2015. Journal of Education for Sustainable Development, 8(2), 89-112. https://doi.org/10.1177/0973408214548360

Sterling, S. (2010). Transformative learning and sustainability: Sketching the conceptual ground. Learning and Teaching in Higher Education, 5, 17-33. http://dl.icdst.org/pdfs/files3/ce3bd9b5c8a4133cd2d81b507badbd85.pdf

Strauss, V. (2013, Aug. 29). Five bad education assumptions the media keeps recycling. The Washington Post Answer Sheet Blog. https://www.washingtonpost.com/news/answersheet/wp/2013/08/29/five-bad-education-assumptions-the-media-keeps-recycling/

Sund, L. \& Pashby, K. (2020). Delinking global issues in northern Europe classrooms. The Journal of Environmental Education, 51(2), 156-170. https://doi.org/10.1080/00958964.2020.1726264

Taylor, M., Watts, J., \& Bartlett, J. (2019, Sep. 27). Climate crisis: 6 million people join latest wave of global protests. The Guardian. https://www.theguardian.com/environment/2019/sep/27/climate-crisis-6-millionpeople-join-latest-wave-of-worldwide-protests 
TCG - Technical Cooperation Group (2019). Proposal for monitoring of SDG indicators 4.7.1, 12.8.1 and 13.3.1 (TCG6/REF/14). UNESCO. http://tcg.uis.unesco.org/wpcontent/uploads/sites/4/2019/08/TCG6-REF-14-Proposal-for-monitoring-of-SDGindicators-4.7.1-12.8.1-and-13.3.1.pdf

TWI2050 - The World in 2050 (2020). Innovations for Sustainability. Pathways to an efficient and post-pandemic future. Report prepared by The World in 2050 initiative. International Institute for Applied Systems Analysis. https://doi.org/10.22022/TNT/07$\underline{2020.16533}$

UN - United Nations (2020). Global indicator framework for the Sustainable Development Goals and targets of the 2030 Agenda for Sustainable Development. UN. https://unstats.un.org/sdgs/indicators/Global\%20Indicator\%20Framework\%20after\%2 02020\%20review_Eng.pdf

UN (2015). Sustainable Development Goals knowledge platform. UN. https://www.un.org/sustainabledevelopment/sustainable-development-goals/

UNESCO - United Nations Educational, Scientific and Cultural Organization (2019). A stepping stone towards monitoring progress towards measuring progress towards SDG 4.7. UNESCO. https://en.unesco.org/news/stepping-stone-towards-measuring-progresstowards-sdg-47

UNESCO - United Nations Educational, Scientific and Cultural Organization (2016). Education for people and planet: creating sustainable futures for all, Global education monitoring report. UNESCO. https://unesdoc.unesco.org/ark:/48223/pf0000245752

UNStats - United Nations Statistics Division (2021). Sustainable Development Goal indicators website. UN. https://unstats.un.org/sdgs/

Wals, A. (2016, Sep. 14). Does the GEM 2016 report signify a change from the dominant neo-liberal agenda that sees education as an extension and a driver of the globalizing economy and its push for infinite growth, innovation and expansion? Learning for sustainability in times of accelerating change. https://transformativelearning.nl/2016/09/14/does-the-gem-2016-report-signify-achange-from-the-dominant-neo-liberal-agenda-that-sees-education-as-an-extensionand-a-driver-of-the-globalizing-economy-and-the-its-push-for-infinite-growth-innovat/

Wals, A. E. J., Weakland, J., \& Corcoran, P. B. (2017). Introduction. In P. B. Corcoran, J. P. Weakland \& A. E. J. Wals (Eds.), Envisioning futures for environmental and sustainability education (pp. 19-29). Wageningen Academic Publishers.

WPR - World Politics Review (2019). The Global Rise of Populism-A WPR Report. WPR. https://www.worldpoliticsreview.com/reports/28252/the-global-rise-of-populism 